Sains Malaysiana 50(1)(2021): 63-72

http://dx.doi.org/10.17576/jsm-2021-5001-07

\title{
The Morphological and Biochemical Effects of Feeding Hooker's Pitcher with Formica fusca or Calliphora vicina Larvae
}

(Kesan Morfologi dan Biokimia terhadap Pemberian Makan Periuk Kera Hooker dengan Formica fusca atau Larva Calliphora vicina)

\author{
JACEK WRÓBEL, MARIOLA WRÓBEL, URSZULA PRZYBYLSKA \& ARKADIUSZ TELESIŃSKI*
}

\begin{abstract}
The aim of this study was to determine if feeding Hooker's pitcher (Nepenthes $\times$ hookeriana) with blowfly larvae (Calliphora vicina Rob-Desvoidy) or ants (Formica fusca L.) affected the plant's biometric and biochemical parameters. The research included measurements of length and width of the laminae and pitchers, and the total contents of the ash, assimilation pigments, polyphenols, and flavonoids. These parameters were measured 30 days after the last feeding. This study demonstrated that feeding the plants with blowfly larvae resulted in increases in the lengths and widths of both the laminae and pitchers. Moreover, the laminae had reduced carotenoid content after feeding with blowfly larvae and ants whereas the pitchers of Hooker's pitcher had increased chlorophyll and carotenoid content after feeding with blowfly larvae. Feeding Hooker's pitcher plants with blowfly larvae also resulted in a reduction of the total polyphenol content in the laminae whereas the total flavonoid content increased in both the laminae and pitchers of Hooker's pitcher. Feeding Nepenthes $\times$ hookeriana with insects ensures that their nutritional needs are met and leads to pitchers with good physiological condition.
\end{abstract}

Keywords: Assimilation pigments; Hooker's pitcher; laminae; pitchers; polyphenols

\section{ABSTRAK}

Tujuan kajian ini adalah untuk menentukan sama ada dengan memberi makan periuk kera Hooker (Nepenthes $\times$ hookeriana) dengan larva langau (Calliphora vicina Rob-Desvoidy) atau semut (Formica fusca L.) dapat mempengaruhi parameter biometrik dan biokimia tumbuhan tersebut. Penyelidikan ini merangkumi pengukuran panjang dan lebar lamina serta periuk kera dan juga kandungan keseluruhan abu, pigmen asimilasi, polifenol serta flavonoid. Parameter ini diukur 30 hari selepas pemberian makanan terakhir. Kajian ini menunjukkan bahawa pemberian makanan kepada tumbuhan ini dengan larva langau meningkatkan panjang dan lebar kedua-dua lamina dan periuk kera. Tambahan pula, kandungan karotenoid lamina berkurangan setelah diberi larva langau dan semut sedangkan terdapat peningkatan kandungan klorofil dan karotenoid selepas periuk kera Hooker diberi larva langau. Pemberian larva langau kepada periuk kera Hooker mengakibatkan pengurangan jumlah kandungan polifenol dalam lamina manakala jumlah kandungan flavonoid meningkat dalam kedua-dua lamina dan periuk kera Hooker. Pemberian serangga kepada Nepenthes $\times$ hookeriana dapat memastikan bahawa keperluan pemakanan mereka dipenuhi dan menghasilkan periuk kera dengan keadaan fisiologi yang baik.

Kata kunci: Lamina; periuk kera; periuk kera Hooker; pigmen asimilasi; polifenol

\section{INTRODUCTION}

Nepenthes $\times$ hookeriana, or Hooker's pitcher plant, is a common natural hybrid of $N$. ampullaria Jack and $N$. rafflesiana var. typica Jack (Rosli et al. 2018). Its natural distribution areas are the tropical forests of Southeast Asia including Borneo, Sumatra, Malaysia, and Singapore, primarily at altitudes of 0 to $500 \mathrm{~m}$ above sea level (Yulita \& Mansur 2012). All species of the genus Nepenthes require climates with high humidity and rich rainfall. Prolonged drought negatively impacts the development and growth of these plants and may even lead to their deaths. Typical habitats for pitcher plants include primary rain forests that are overgrown with Dipterocarpus trees, swamp woods, Erica forests, mountain forests, the upper and lower stories of cloud forests, steep slopes, saltwater mangrove forests, rocky cliffs, areas of destroyed and recovering secondary vegetation (such as after forest cutting, roadsides, and pastures) and bushes and pine forests subject to seasonal drought (Setiawan et al. 2015). 
Insectivorous plants grow in acidic and marshy areas, which have reduced nutrient levels while noninsectivorous plants generally obtain nutrients from the soil (Adamec 1997). Compared to other plants, pitcher plant roots are markedly smaller and thinner, and may constitute 3.4 to $23 \%$ of the plant total biomass. The roots are unable to obtain the necessary nutrients from the soil, and so the plants require an alternative method of nutrient absorption (Adlassing et al. 2005; Bechie \& Bidochka 2013). Therefore, Nepenthes plants have developed pitchers which constitute a perfect mechanism for luring and catching small insects.

The inside of the upper portion of a pitcher is covered with microscopic, waxy plates that are set like tiles which break off under the weight of a standing insect and adhere to its legs, thus reducing its grip level. The insect is unable to stay on the wall and falls down into the trap (Bazile et al. 2015). The plant has glands that secrete a sweet substance that lures insects; these glands are located on the lids and rims of the pitcher openings. The shapes and sizes of the glands vary by the level of the feeding zone. They are smaller in the upper portion, with an oval or elongated shape whereas at the bottom they are noticeably larger and may even attain a wavy shape (Wang et al. 2009a). Liquid (a mixture of rainwater and nonnectar plant secretions) accumulates in the lower portion of the pitcher and on the outside of the lip that encircles the pitcher opening. By attempting to collect the nectar, insects place themselves over the pitcher opening, with each careless movement resulting in the insects slipping further down the pitcher (Moran \& Clarke 2010). The bodies of prey are decomposed by digestive enzymes secreted by the glands located in the lower portion of the pitcher (Adlassing et al. 2011; Miguel et al. 2018). Pitchers can produce from $0.2 \mathrm{~mL}$ to $1.5 \mathrm{~L}$ of the digestive liquid, which is acidic (with $\mathrm{pH} 3.0$ to 5.5), viscous, rich in oxygen and contains digestive enzymes (Ravee et al. 2018). Pitchers primarily obtain nitrogen and phosphorus from insects (Bechie \& Bidochka 2013). Typical pitcher preys include beetles, ants, termites, flies, wasps, moths, and cockroaches (Rischer et al. 2002).

Pavlovič et al. (2009) reported that feeding $N$. talangensis with meal worm (Tenebrio molitor) resulted in an increase in the chlorophyll and nitrogen contents of the laminae and stimulation of the rate of photosynthesis and utilisation of absorbed light energy for photochemistry in plants. In contrast to the laminae, the pitchers are unable to increase their rates of photosynthesis $\left(\mathrm{A}_{\mathrm{N}}\right)$ in response to feeding, suggesting that they are highly specialised for nutrient acquisition. The ability of the laminae to increase biomass and photosynthetic efficiency in response to prey capture may provide a competitive advantage for these plants over non-carnivorous plants in sunny and nutrientpoor habitats. Moran and Moran (1998) studied the benefits of carnivory on some parameters of $N$. rafflesiana and showed that resource limitations caused decreases in chlorophyll content and increases in the production of anthocyanins, denoting possible nitrogen or phosphorus limitation.

Miguel et al. (2018) reported that Nepenthes species have developed a number of ecological traits that have attracted the attention of plant biologists. The different adaptation strategies that these plants have developed make them a source of inspiration for many applications, from therapeutic treatments to agricultural biocontrol solutions. More recent reports described the use of different species of Nepenthes in phytotherapy (Dhamecha et al. 2016). In the folk medicine of India and Southeast Asian countries, they are used in the treatment of leprosy, cholera, night blindness, gastrointestinal discomfort, dysentery, stomachache, and bed-wetting, among other ailments (Sanusi et al. 2017). The phytochemical compounds isolated from Nepenthes species include polyphenols, terpenoids, tannins, alkaloids, and steroids (Thanh et al. 2015).

The aim of the study was to determine if feeding Hooker's pitcher with blowfly larvae or ants affected the plant morphological measurements (i.e. the lengths and widths of the laminae and pitchers) and the ash, assimilation pigment, total polyphenol and total flavonoid contents.

\section{MATERIALS AND METHODS}

\section{EXPERIMENTAL DESIGN AND SAMPLING}

The laboratory experiment was conducted using 18 individual Nepenthes $\times$ hookeriana Hort. Veitch ex Mast. ( $N$. ampullaria Jack $\times N$. rafflesiana var. typica Jack) plants, which were obtained from Carnisana (Sosnowiec, Poland). Plants grown in greenhouse conditions in pots were placed in trays with small amounts of distilled water to maintain substrate humidity. Plants in the same developmental stages that did not differ morphologically were selected for the experiment. There were four mature pitchers on each plant.

The experimental plants were divided into three groups (six individuals in each group) where the first group of Hooker's pitcher received only water, the second was watered and fed with blowfly larvae (Calliphora vicina Rob-Desvoidy, Diptera), and the third group was watered and fed with ants (Formica fusca L., Hymenoptera). The insects used in the experiment were obtained from our own breeding in the Department of Bioengineering of West Pomeranian University of Technology in Szczecin, Poland. The plants were fed three times, at the beginning of the experiment (day 0), day 10 and day 20. For feeding the plants, one blowfly larva or a weight-equivalent number of ants were added to each pitcher. The blowfly larvae were 
selected such that each plant received a similarly-sized larva. Before being added to the pitchers, the larvae were weighed on a Petri dish. The average larval weight was $20 \pm 2 \mathrm{mg}$. The ants were also weighed on a Petri dish and also weighed, on average at $20 \pm 2 \mathrm{mg}$. There were 3 to 4 ants per blowfly larva. The average number of introduced insects was $23 \pm 2 \mathrm{mg}$ per plant over 20 days. Throughout the experiment, growth conditions were maintained at ideal conditions for Hooker's pitcher. Thirty days after the last feeding, the biometrical measurements of the laminae and pitchers, as well as their assimilation pigment, total polyphenol, total flavonoid and ash contents were measured.

\section{BIOMETRIC MEASUREMENTS}

For biometric measurements, digital recordings were performed using a photographic camera GH5 (UK and Ireland). To standardise the results, a ruler was placed within the frame of view while taking pictures. The lengths and widths of the laminae and pitchers were measured with the aid of an image analysis program (ImageJ). For each measurement, the distance measurement was calibrated according to the ImageJ instruction manual. The lengths were measured without including any tendrils. The width measurement was based on the widest region. The lengths and widths of the laminae and pitchers were given as the percentage change $(P C h)$ calculated according to the formula in (1):

$$
P C h=\frac{A_{F}-A_{0}}{A_{F}} \cdot 100 \%
$$

where $A_{F}$ is the final length or width, and $A_{0}$ is the starting length or width. The results of the changes in lengths and widths were presented in the form of percentage changes, which allowed for a better comparison and eliminated possible differences at the beginning of the experiment.

\section{DETERMINATION OF ASSIMILATION PIGMENT AND ASH CONTENTS}

Photosynthetic pigment contents were determined according to the method reported by Arnon et al. (1956), as modified by Lichtenthaler and Welburn (1983). Accordingly, for each plant, $100 \mathrm{mg}$ of laminae and $50 \mathrm{mg}$ of pitchers were homogenised in $10 \mathrm{~mL}$ of $80 \%$ acetone using a mortar and pestle, and the homogenates were collected in a centrifuge tube. The samples were centrifuged at 1,500 rpm for $10 \mathrm{~min}$ using a MicroCL 21R centrifuge (Thermo). The supernatants were used for the determination of pigment contents. The chlorophyll $a$ (Chla), chlorophyll $b(\mathrm{Chl} b)$ and carotenoid (Car) contents were determined by measuring the absorbance at 440, 645, and $663 \mathrm{~nm}$, respectively, using a MarcelMini spectrophotometer (Zielonka, Poland). For each plant, the assimilation pigments were measured in quadruplicate. The amount of assimilation pigments present was expressed as $\mathrm{mg} / \mathrm{kg}$ fw.

In order to assess the total amount of minerals, the total ash content was determined. The method for determining the total ash involved incinerating the analytical sample at $550{ }^{\circ} \mathrm{C}$ in a muffle furnace until the organic substances were completely burnt, after which the weight determination of the residues was performed (AOAC 2000).

\section{DETERMINATION OF TOTAL POLYPHENOL AND TOTAL FLAVONOID CONTENTS}

Total polyphenol and total flavonoid contents were determined by the methods of Yu et al. (2002) and Kumaran and Karunakaran (2007), respectively. Accordingly, for each plant, $100 \mathrm{mg}$ of the plant material was homogenised in $10 \mathrm{~mL}$ of $80 \%$ methanol using a mortar and pestle and the homogenate was collected in a centrifuge tube. The samples were centrifuged for $5 \mathrm{~min}$ at 14,800 rpm using a MicroCL 21R centrifuge (Thermo). The supernatants were used for the determination of the total polyphenol and flavonoid contents. For each plant, the extracts were prepared in quadruplicate.

To determine the total polyphenol content, 0.1 $\mathrm{mL}$ of supernatant was mixed with $0.5 \mathrm{~mL}$ of the FolinCiocalteu reagent and $1.5 \mathrm{~mL}$ of $20 \%$ sodium carbonate. The mixture was shaken thoroughly and the solution volume was increased to $10 \mathrm{~mL}$ using distilled water. Afterwards, the samples were incubated for $2 \mathrm{~h}$ at 25 ${ }^{\circ} \mathrm{C}$. Then, the absorbance at $765 \mathrm{~nm}$ was determined. These data were used to estimate the total polyphenol content using a standard curve obtained from various concentrations of gallic acid.

To determine the total flavonoid content, $1 \mathrm{~mL}$ of supernatant was mixed with $1 \mathrm{~mL}$ of $2 \%$ aluminum chloride and a drop of glacial acetic acid. The samples were shaken at room temperature for $40 \mathrm{~min}$. After this time, each sample volume was increased to $25 \mathrm{~mL}$ with methanol and the absorbance was determined against a reagent blank at wavelength, $\lambda$, of $415 \mathrm{~nm}$. These data were used to estimate the total flavonoid content using a standard curve obtained from various concentrations of quercetin. A UV-1800 spectrophotometer (Shimadzu, Japan) was used to determine the total polyphenol and total flavonoid contents.

\section{STATISTICAL ANALYSIS}

All the biometric and biochemical parameter data were analysed using STATISTICA 13.1. The data were analysed using a two-way ANOVA test followed by Tukey's HSD post hoc test. Differences were considered significant at the $P<0.05$ level. All results were expressed 
as mean \pm standard deviation. Moreover, Pearson's correlation coefficients were calculated among the assayed biochemical parameters. $P$-values were corrected for multiple testing using the Bonferroni correction (Ramette 2007).

\section{RESULTS}

\section{INFLUENCE OF FEEDING HOOKER'S PITCHER WITH INSECTS ON THE BIOMETRIC MEASUREMENTS OF LAMINAE AND PITCHERS}

Watering the plants caused mean increases in the widths of laminae and pitchers of 9.21 and $13.18 \%$, respectively. After feeding the plants with blowfly larvae, the mean width increases in the laminae and pitchers were 33.33 and $24.91 \%$, respectively, whereas after feeding the plants with ants, the mean width increases in the laminae and pitchers were 12.09 and $15.32 \%$, respectively (Figure 1(a)). The statistical analysis showed significant differences only between the widths of laminae fed with blowfly larvae and the laminae of watered plants.

The mean percentage changes in the lengths of the laminae and pitchers of watered-only Hooker's pitcher were 9.30 and $11.14 \%$, respectively. The mean percentage changes in the lengths of the laminae and pitchers of plants fed with blowfly larvae were 20.32 and $18.56 \%$, respectively, and those of plants fed with ants were 15.52 and $14.89 \%$, respectively (Figure 1(b)). The statistical analysis showed significant differences only between the lengths of laminae fed with blowfly larvae and the laminae of watered plants.
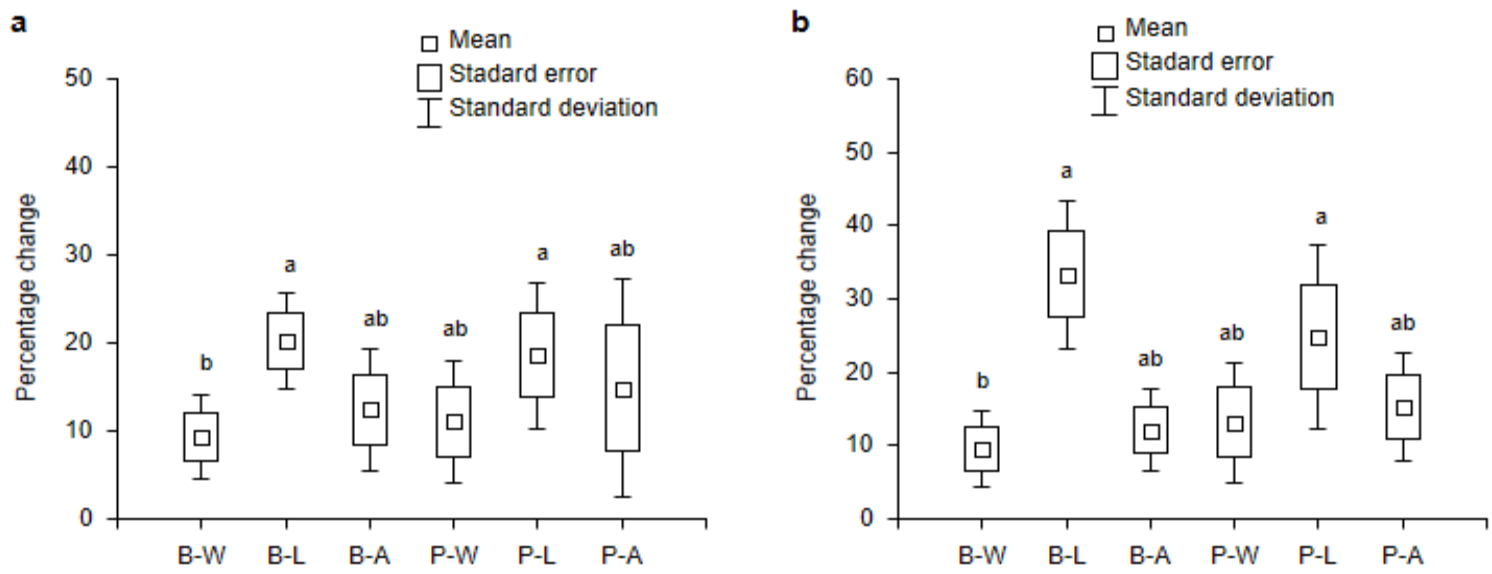

FIGURE 1. Percentage changes in (a) width, and (b) length of Hooker's pitcher laminae (B) and pitchers (P); $\mathrm{W}$ - plants that only received water, $\mathrm{L}$ - plants fed with blowfly larvae, and A - plants fed with ants. Values are mean values $\pm \mathrm{SD}(\mathrm{n}=6)$, different letters show significant differences at $P<0.05$ (post hoc Tukey's HSD test)

\section{INFLUENCE OF FEEDING HOOKER'S PITCHER WITH INSECTS ON THE ASSIMILATION PIGMENT CONTENTS IN LAMINAE AND PITCHERS}

The Chl $a$ and Chl $b$ contents in the laminae of Hooker's pitcher did not change significantly after feeding the plants with blowfly larvae or ants, whereas the Car content was reduced after feeding the plants with blowfly larvae or ants by 21.23 or $26.70 \%$, respectively, compared to watered-only plants. However, in the pitchers of Hooker's pitcher fed with blowfly larvae, the contents of Chla, Chlb, and Car increased by $91.33,80.27$, and
$89.85 \%$, respectively, in comparison to watered-only plants (Table 1). In laminae, the $\mathrm{Chl} a / \mathrm{Chl} b$ ratio did not change in either feeding regimen, whereas in pitchers, there was a $32.88 \%$ increase in this ratio after feeding with ants, compared to watered-only plants. There were interesting changes in the $(\mathrm{Chl} a+\mathrm{Chl} b) / \mathrm{Car}$ ratio in laminae. In plants fed with blowfly larvae or ants, this ratio increased by 29.11 or $32.49 \%$, respectively, whereas for pitchers, a statistically significant increase in the $(\mathrm{Chl} a+\mathrm{Chl} b) / \mathrm{Car}$ ratio was observed only after feeding with ants $(25.58 \%$, compared to watered-only plants). 
TABLE 1. Content of assimilation pigments $(\mathrm{mg} / \mathrm{kg}$ fw) in Hooker's pitcher; values are mean values $\pm \mathrm{SD}$, different letters show significant differences at $P<0.05$ (post hoc Tukey's HSD test)

\begin{tabular}{|c|c|c|c|c|c|c|}
\hline $\begin{array}{l}\text { Part of } \\
\text { plants }\end{array}$ & Feeding & Chla & Chl $b$ & Car & Chl $a / \mathrm{Chl} b$ & $\begin{array}{c}(\mathrm{Chl} a+\mathrm{Chl} b) / \\
\text { Car }\end{array}$ \\
\hline \multirow{3}{*}{ Laminae } & W & $738.15 \pm 48.63^{\mathrm{a}}$ & $304.28 \pm 18.34^{\mathrm{a}}$ & $440.38 \pm 40.28^{\mathrm{a}}$ & $2.43 \pm 0.07^{\mathrm{a}}$ & $2.37 \pm 0.07^{\mathrm{d}}$ \\
\hline & $\mathrm{L}$ & $745.69 \pm 18.82^{\mathrm{a}}$ & $288.69 \pm 9.29^{a}$ & $346.89 \pm 17.85^{b}$ & $2.58 \pm 0.02^{\mathrm{a}}$ & $3.06 \pm 0.26^{c}$ \\
\hline & A & $721.84 \pm 43.15^{\mathrm{a}}$ & $287.60 \pm 30.03^{\mathrm{a}}$ & $322.79 \pm 32.05^{b}$ & $2.52 \pm 0.11^{\mathrm{a}}$ & $3.14 \pm 0.18^{\mathrm{b}}$ \\
\hline \multirow{3}{*}{ Pitchers } & W & $115.59 \pm 24.58^{c}$ & $79.98 \pm 19.74^{c}$ & $65.05 \pm 8.89^{\mathrm{d}}$ & $1.46 \pm 0.09^{\mathrm{c}}$ & $3.01 \pm 0.27^{\mathrm{c}}$ \\
\hline & $\mathrm{L}$ & $221.16 \pm 37.49^{b}$ & $144.18 \pm 17.81^{b}$ & $123.50 \pm 5.02^{\mathrm{c}}$ & $1.52 \pm 0.12^{\mathrm{c}}$ & $3.05 \pm 0.18^{\mathrm{c}}$ \\
\hline & $\mathrm{A}$ & $128.26 \pm 19.80^{\circ}$ & $65.66 \pm 13.11^{\mathrm{c}}$ & $51.72 \pm 2.47^{d}$ & $1.94 \pm 0.10^{\mathrm{b}}$ & $3.78 \pm 0.21^{\mathrm{a}}$ \\
\hline
\end{tabular}

Chl $a$ chlorophyll $a, \mathrm{Ch} b$ chlorophyll $b$, Car carotenoids, W watered-only plants, L plants fed with blowfly larvae, A plants fed with ants

\section{INFLUENCE OF FEEDING HOOKER'S PITCHER WITH INSECTS ON THE CONTENT OF POLYPHENOLIC COMPOUNDS IN LAMINAE AND PITCHERS}

The total polyphenol content in the laminae of Hooker's pitcher was significantly reduced after feeding the plants with blowfly larvae (18.19\%, compared to watered-only plants), but this was not significantly affected by feeding the plants with ants. No significant change in total polyphenol content was observed in the pitchers after either feeding regime (Figure 2(a)).
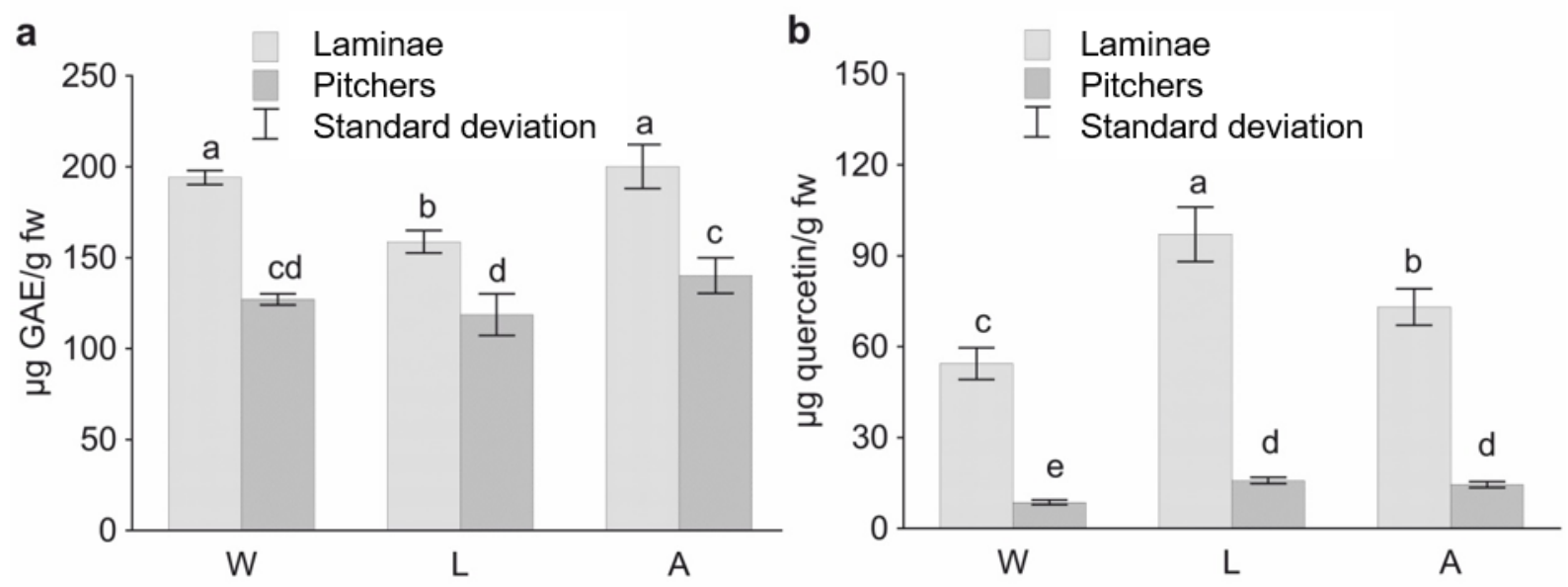

FIGURE 2. Content of (a) total polyphenols, and (b) total flavonoids in Hooker's pitcher laminae and pitchers; $\mathrm{W}$ - plants that only received water, $\mathrm{L}$ - plants fed with blowfly larvae, A - plants fed with ants, GAE - gallic acid equivalents. Values are mean values $\pm \mathrm{SD}$, different letters show significant differences at $P<0.05$ (post hoc Tukey's HSD test)

However, the total flavonoid content increased in both the laminae and pitchers of Hooker's pitcher after the plants were fed with the insects. In the laminae, feeding with blowfly larvae or ants led to increases of 78.34 or
$34.28 \%$, respectively, compared to watered-only plants, whereas pitchers fed with blowfly larvae or ants showed increases of 83.33 or $68.29 \%$, respectively (Figure 2(b)). 
INFLUENCE OF FEEDING HOOKER'S PITCHER WITH INSECTS ON ASH CONTENT IN LAMINAE AND PITCHERS OF HOOKER'S PITCHER

The ash content in the laminae and pitchers of Hooker's pitcher did not change after feeding with blowfly larvae, compared to watered-only plants. However, feeding with ants resulted in statistically significant reductions in the ash contents of both the laminae and pitchers, which amounted to 53.33 and $45.54 \%$, respectively, when compared to watered-only plants (Figure 3).

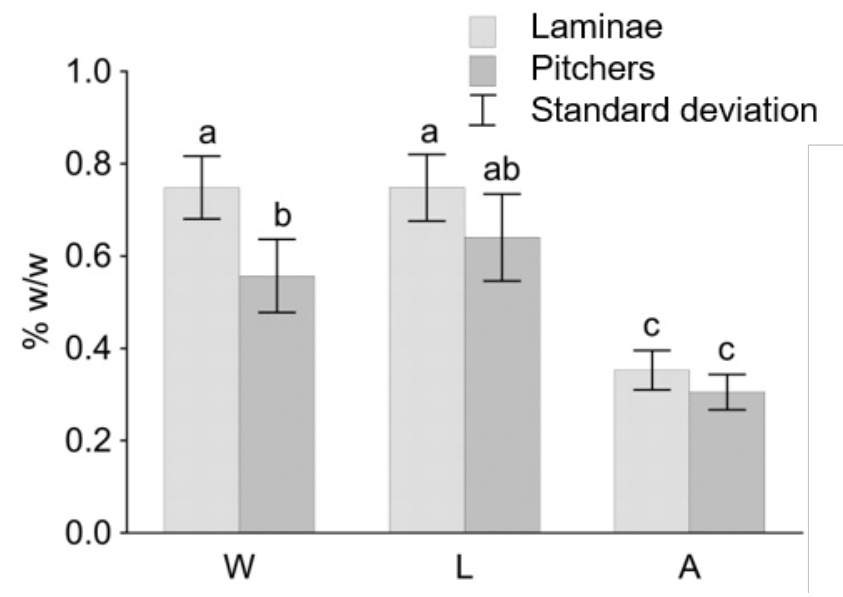

FIGURE 3. Content of ash in Hooker's pitcher laminae and pitchers; W - plants that only received water, $\mathrm{L}$ - plants fed with blowfly larvae, A - plants fed with ants. Values are mean values $\pm \mathrm{SD}$ of four replicates, different letters show significant differences at $P<0.05$ (post hoc Tukey's HSD test)

RELATIONSHIP BETWEEN BIOCHEMICAL PARAMETERS OF LAMINAE AND PITCHERS OF HOOKER'S PITCHER

Based on the calculated Pearson's correlation coefficients with the Bonferroni correction, a positive relationship was found between the majority of the determined parameters in the laminae and pitchers of Hooker's pitcher.
The highest correlation coefficient (0.987) was recorded between the Chl $a$ and $\mathrm{Chl} b$ content (Table 2). However, no significant relationship was observed between the $(\mathrm{Chl} a+\mathrm{Chl} b) / \mathrm{Car}$ ratio and the majority of the parameters determined.

TABLE 2. Pearson's correlation coefficients at the Bonferroni-corrected level among assayed parameters in laminae and pitchers of Hooker's pitcher

\begin{tabular}{lcccccccc}
\hline \multicolumn{1}{c}{ Parameter } & Chl $a$ & Chl $b$ & Car & Chl $a / \mathrm{Chl} b$ & $(\mathrm{Chl} a+\mathrm{Chl} b) / \mathrm{Car}$ & Phe & Flav & Ash \\
\hline Chl $a$ & & 0.000 & 0.000 & 0.000 & 0.498 & 0.000 & 0.000 & 0.000 \\
Chl $b$ & $0.987^{*}$ & & 0.000 & 0.000 & 0.356 & 0.000 & 0.000 & 0.000 \\
Car & $0.955^{*}$ & $0.959^{*}$ & & 0.000 & 0.107 & 0.000 & 0.000 & 0.000 \\
Chl $/$ Chl $b$ & $0.903^{*}$ & $0.831^{*}$ & $0.815^{*}$ & & 0.734 & 0.000 & 0.000 & 0.002 \\
$(\mathrm{Chl} a+\mathrm{Chl} b) / \mathrm{Car}$ & -0.298 & -0.339 & -0.494 & -0.066 & & 0.473 & 0.617 & 0.314 \\
Phe & $0.824^{*}$ & $0.790^{*}$ & $0.791^{*}$ & $0.806^{*}$ & -0.257 & & 0.011 & 0.019 \\
Flav & $0.906^{*}$ & $0.866^{*}$ & $0.773^{*}$ & $0.872^{*}$ & -0.115 & 0.675 & & 0.006 \\
Ash & $0.865^{*}$ & $0.896^{*}$ & $0.887^{*}$ & 0.711 & -0.307 & 0.556 & 0.736 & \\
\hline
\end{tabular}

$P$-values of correlations are shown in the upper right part of the table; *denotes significant coefficients at the Bonferroni-corrected level $(p \leq 0.000521)$ which are additionally shown in bold for better visualization; Chl chlorophyll, Car carotenoids, Phe total polyphenols, Flav total flavonoids 


\section{DISCUSSION}

This study examined the effects of feeding Hooker's pitcher with blowfly larvae (Calliphora vicina Rob-Desvoidy) or ants (Formica. fusca L.) based on the biometric and biochemical parameters of the laminae and pitchers.

The results demonstrated that feeding the plants with blowfly larvae resulted in increases in the lengths and widths of laminae and pitchers, whereas feeding the plants with ants had minor effects on the biometric characteristics of laminae and pitchers. The available literature does not provide information on the influence of feeding Hooker's pitcher on the plants' morphological parameters. However, Moran et al. (1999) and Osunkoya et al. (2007) who compared various Nepenthes species demonstrated that the $N$. mirabilis species was characterised by the longest and the widest pitchers. Moreover, Marina et al. (2018) reported that of the 901 total fauna trapped in the pitchers of Nepenthes spp. grown in Bukit Setiam Forest, Malaysia, $58.82 \%$ belonged to the order Hymenoptera (primarily ant species) and $15.78 \%$ belonged to the order Diptera $(15.87 \%)$. Some studies have also demonstrated that selected ant species inhabit the outside of pitcher plants (Bazile et al. 2012; Grafe \& Kohout 2013; Thornham et al. 2012). Therefore, we chose ants and blowfly larvae for our research, the largest quantities of which were found in the pitchers.

In this study, laminae were found to have reduced Car content as a result of feeding with blowfly larvae and ants, whereas the pitchers of Hooker's pitcher had increased chlorophyll content, as well as carotenoid content, after feeding with blowfly larvae. Pavlovič et al. (2009) demonstrated that feeding $N$. talangensis with Tenebrio molitor larvae for 2 months resulted in an increased photosynthesis rate and optimal efficiency of PSII $\left(F_{\mathrm{v}} / F_{\mathrm{m}}\right)$ in both the leaves and pitchers. The optimal efficiency of PSII $\left(F_{\mathrm{v}} / F_{\mathrm{m}}\right)$ is an important indicator of photochemical efficiency in plants (Maxwell \& Johnson 2000; Tušek et al. 2016). Feeding pitchers with insect larvae increased the rate of photosynthesis $\left(\mathrm{A}_{\mathrm{N}}\right)$ in leaf laminae due to increased nutrient acquisition, with a strong correlation with nitrogen concentration, but the $\mathrm{A}_{\mathrm{N}}$ of pitchers did not increase despite the increased nitrogen concentrations in their tissue. Increasing the $A_{N}$ improved growth and reproduction and was likely to increase the competitive advantage of carnivorous over non-carnivorous plants in nutrient-poor habitats (Pavlovič et al. 2009). Increased $A_{N}$ after feeding was also found by Farnsworth and Ellison (2008) in the genus Sarracenia. Moreover, He and Zain (2012) showed that maximal light-saturated photosynthetic rates $\left(P_{\max }\right)$ were higher in leaves than in pitchers. Moran and Moran (1998) reported a reduction in chlorophyll content and increased production of anthocyanins in the leaves of $N$. rafflesiana plants that were not deprived of their ability to develop in their natural habitat. The rate of photosynthesis was not increased as a result of prey capture in the carnivorous butterwort Pinguicula vulgaris (Méndez \& Karlsson 1999). However, supplementary feeding increased both rosette size and reproduction through an increase in flowering frequency (Thorén \& Karlsson 1998).

The relationships between the chlorophyll and carotenoid contents, namely the $\mathrm{Chl} a / \mathrm{Chl} b$ ratio and $(\mathrm{Chl} a+\mathrm{Chl} b) / \mathrm{Car}$ ratio, constitute very important markers of physiological changes (Biczak et al. 2017; Netto et al. $2005)$. Changes in the $\mathrm{Chl} a / \mathrm{Chl} b$ value clearly indicate the occurrence of oxidative stress in plants and indicate the activation of the plants' defenses (Pawłowska et al. 2017). On the other hand, a significant decrease in Chla content may indicate considerable damage to photosystems (Chen et al. 2014; Wang et al. 2009b). This study demonstrated that significant increases in the $\mathrm{Chl} a / \mathrm{Chl} b$ ratio occurred solely in pitchers after feeding with ants. Similar results were found by Pavlovič et al. (2009) in fed and unfed N. talangensis plants. However, the observed changes in the $(\mathrm{Chl} a+\mathrm{Chl} b) / \mathrm{Car}$ ratio were interesting for laminae where the increase was observed after feeding plants with blowfly larvae as well as after feeding them ants, but this parameter was increased in pitchers only after feeding the plants with ants. Carotenoids are necessary for photoprotection of photosynthesis and they play an important role as a precursor in signaling during plant development under abiotic/biotic stress (Ashraf \& Harris 2013). They have a significant potential to enhance nutritional quality and plant yield. Nowadays, enhanced carotenoid contents in plants are strongly considered for breeding as well as genetic engineering in different plants ( $\mathrm{Li}$ et al. 2008). Carotenoids are also present in plant cellular membranes. They protect the membranes from light-dependent oxidative damage. The role of carotenoids in scavenging reactive oxygen species has been well studied (Davison et al. 2002; Pawłowska et al. 2017; Verma \& Mishra 2005).

This study has demonstrated that feeding Hooker's pitcher with blowfly larvae resulted in a reduction of the total polyphenol content in the laminae, whereas the total polyphenol content in both the laminae and pitchers of Hooker's pitcher increased after the plants were fed with ants. Carnivorous plants are characterised by the synthesis of secondary metabolites in the insect-trap tissues, which are used for self-defense (Rischer et al. 2002). Eilenberg et al. (2010) reported that diverse bioactive allelochemicals including alkaloids, terpenes, and phenolics, were found in many representatives of different families of carnivorous plants. The synthesis of protective secondary metabolites is very common in many plants and occurs in response to chemical, biotic or physical stresses (Bringmann \& Feineis 2001; Rischer et al. 2002).

The ash content in the laminae was higher than in the pitchers, especially in unfed Hooker's plants. This 
was consistent with the results obtained by Osunkoya et al. (2007). Pavlovič et al. (2009) showed the increase in the dry matter of laminae of $N$. talangensis fed with insect larvae. However, in our study, the ash content in Hooker's plants did not differ significantly between those fed blowfly larvae and those who were only watered. Moreover, feeding with ants resulted in statistically significant decreases in the ash contents of both the laminae and pitchers. This probably occurred because ants have chitin armor. From a similar mass of digested prey bodies, more is extracted from blowfly larvae and thus more ash is formed.

Based on the calculated Pearson's correlation coefficients, a positive relationship was found between the majority of the determined parameters in the laminae and pitchers of Hooker's pitcher. Tušek et al. (2016) found that variations in the photochemical efficiency and content of photosynthetic pigments and phenolic compounds correlated with the function of the pitcher of Sarracenia. The red-colored operculum and upper pitcher part which has the role of luring and catching prey, contains more phenolic compounds especially anthocyanins which help to attract insects. Moreover, a lower photochemical efficiency has often been observed in carnivorous plants (Bruzzese et al. 2010) and has been correlated with the costs of carnivory (Adamec 2010) as well as with low foliar nitrogen content and the slow growth of carnivorous plants (Ellison \& Adamec 2011; Pavlovič \& Saganová 2015). Karagatzides and Ellison (2009) measured massbased construction costs and photosynthesis for the traps, leaves, roots, and rhizomes of 15 carnivorous plant species grown under greenhouse conditions. They found that the mean value construction costs (CC) mass of carnivorous traps was significantly lower than the $\mathrm{CC}$ mass of leaves of 267 non-carnivorous plant species. Moreover, Osunkoya et al. (2007) reported that the $\mathrm{CC}$ of the assimilatory organs for the pitcher was in agreement with the concept of low marginal cost for carnivory, relative to conventional autotrophy. The poor explanatory power of N, P or the $\mathrm{N}: \mathrm{P}$ ratio with $\mathrm{CC}$ suggests that factors other than the production of expensive photosynthetic machinery (which calls for a high $\mathrm{N}$ input) including concentrations of lignin, wax/lipids or osmoregulatory ions like $\mathrm{K}^{+}$, may give a better explanation of the $\mathrm{CC}$ variations across Nepenthes species.

Feeding Nepenthes plants with insects in various forms ensures that their nutritional needs are met and leads to pitchers with good physiological conditions (physiological activity), which was confirmed by the results of our studies. Providing plants with additional minerals during the growth period from insect digestion prevents, among other things, the appearance of physiological diseases on laminae (chlorosis, necrosis) and on pitchers (necrosis) caused by a deficiency of essential minerals for cultivation without feeding. Therefore, the knowledge presented here regarding the biochemical and physiological responses of Hooker's pitcher to insect feeding may be useful in the breeding of this species.

\section{CONCLUSION}

The available literature contains little information on how feeding insectivorous plants affects the plant morphological and biochemical parameters. This study demonstrated that feeding plants $C$. vicina larvae resulted in increases in the lengths and widths of laminae and pitchers, whereas feeding the plants $F$. fusca had minor effects on the biometric characteristics of the laminae and pitchers. Moreover, the laminae had reduced carotenoid content after feeding on C. vicina larvae and F. fusca, whereas the pitchers of Hooker's pitcher had increased chlorophyll and carotenoid contents after feeding on $C$. vicina larvae. Furthermore, feeding Hooker's pitcher $C$. vicina larvae resulted in a reduction of the total polyphenol content in laminae, whereas the total flavonoid contents in laminae and pitchers increased after feeding the plants with either F. fusca or C. vicina larvae. Analysis of the Pearson's correlation coefficients demonstrated a positive relationship between the majority of the parameters in the laminae and pitchers of Hooker's pitcher.

\section{REFERENCES}

Adamec, L. 2010. Dark respiration of leaves and traps of terrestrial carnivorous plants: Are there greater energetic costs in traps? Central European Journal of Biology 5: 121-124.

Adamec, L. 1997. Mineral nutrition of carnivorous plants: A review. The Botanical Review 63(3): 273-299.

Adlassing, W., Peroutka, M. \& Lendl, T. 2011. Traps of carnivorous pitcher plants as a habitat: Composition of the fluid, biodiversity and mutualistic activities. Annals of Botany 107: 181-194.

Adlassing, W., Peroutka, M., Lambers, H. \& Lichtscheidl, I.K. 2005. The roots of carnivorous plants. Plant and Soil 274: 124-140.

Arnon, D.I., Allen, M.B. \& Whatley, F.R. 1956. Photosynthesis by isolated chloroplasts. Biochimica et Biophysica Acta 20: 449-461.

Ashraf, M. \& Harris, P.J.C. 2013. Photosynthesis under stressful environments: An overview. Photosynthetica 51(2): 163-190.

AOAC. 2000. Official Methods of Analysis of AOAC International. Association of Official Analytical Chemists (AOAC).

Bazile, V., Le Moguédec, G., Marshall, D. \& Gaume, L. 2015. Fluid physico-chemical properties influence capture and diet in Nepenthes pitcher plants. Annals of Botany 115: 705-716.

Bazile, V., Moran, J.A., Le Moguédec, G., Marshall, D.J. \& Gaume, L. 2012. A carnivorous plant fed by its ant symbiont: A unique multi-faceted nutritional mutualism. PLOS ONE 7(5): e36179. 
Bechie, S.W. \& Bidochka, M.J. 2013. Insects as a nitrogen source for plants. Insects 4(3): 413-424.

Biczak, R., Śnioszek, M., Telesiński, A. \& Pawłowska, B. 2017. Growth inhibition and efficiency of the antioxidant system in spring barley and common radish grown on soil polluted ionic liquids with iodide anions. Ecotoxicology and Environmental Safety 139: 463-471.

Bringmann, G. \& Feineis, D. 2001. Stress-related polyketide metabolism of Dioncophyllaceae and Ancistrocladaceae. Journal of Experimental Botany 52: 2015-2022.

Bruzzese, B.M., Bowler, R., Massicotte, H.B. \& Fredeen, A.L. 2010. Photosynthetic light response in three carnivorous plant species: Drosera rotundifolia, D. capensis and Sarracenia leucophylla. Photosynthetica 48: 103-109.

Chen, Y., Lin, F., Yang, H., Yue, L., Hu, F., Wang, J., Luo, Y. \& Cao, F. 2014. Effect of varying $\mathrm{NaCl}$ doses on flavonoid production in suspension cells of Ginkgo biloba: Relationship to chlorophyll fluorescence, ion homeostasis, antioxidant system and ultrastructure. Acta Physiologiae Plantarum 36: 3173-3187.

Davison, P.A., Hunter, C.N. \& Horton, P. 2002. Overexpression of $\beta$-carotene hydroxylase enhances stress tolerance in Arabidopsis. Nature 418: 203-206.

Dhamecha, D., Jalalpure, S. \& Jadhav, K. 2016. Nepenthes khasiana mediated synthesis of stabilized gold nanoparticles: Characterization and biocompatibility studies. Journal of Photochemistry and Photobiology B: Biology 154: 108-117.

Eilenberg, H., Pnini-Cohen, S., Rahamim, Y., Sionov, E., Segal, E., Carmeli, S. \& Zilberstein, A. 2010. Induced production of antifungal naphthoquinones in the pitchers of the carnivorous plant Nepenthes khasiana. Journal of Experimental Botany 61(3): 911-922.

Ellison, A.M. \& Adamec, L. 2011. Ecophysiological traits of terrestrial and aquatic carnivorous plants: Are the costs and benefits the same? Oikos 120: 1721-1731.

Farnsworth, E.J. \& Ellison, A.M. 2008. Prey availability directly affects physiology, growth, nutrient allocation and scaling relationships among leaf traits in 10 carnivorous plant species. Journal of Ecology 96: 213-221.

Grafe, T.U. \& Kohout, R.J. 2013. A new case of ants nesting in Nepenthes pitcher plants. Ecotropica 19: 77-80.

He, J. \& Zain, A. 2012. Photosynthesis and nitrogen metabolism of Nepenthes alata in response to inorganic $\mathrm{NO}_{3}^{-}$and organic prey $\mathrm{N}$ in the greenhouse. International Scholarly Research Notices 2012: Article ID. 263270.

Karagatzides, J.D. \& Ellison, A.M. 2009. Construction costs, payback times, and the leaf economics of carnivorous plants. American Journal of Botany 96: 1612-1619.

Kumaran, A. \& Karunakaran, R.J. 2007. In vitro antioxidant activities of methanol extracts of five Phyllanthus species from India. Food Science and Technology 40: 344-351.

Li, F., Vallabhaneni, R., Yu, J., Rocheford, T. \& Wurtzel, E.T. 2008. The maize phytoene synthase gene family: Overlapping roles for carotenogenesis in endosperm, photomorphogenesis and thermal stress tolerance. Plant Physiology 147: 1334-1346.

Lichtenthaler, H. \& Wellburn, A. 1983. Determination of total carotenoids and chlorophyll $a$ and $b$ of leaf extracts in different solvents. Biochemical Society Transactions 603: 591-592.

Marina, M.T., Keen, C.J., Caroline, B.R. \& Afsar, J. 2018. Fauna diversity in pitcher plants at Setiam Hill, Bintulu, Sarawak, Malaysia. Sains Malaysiana 47(1): 19-25.

Maxwell, K. \& Johnson, G.N. 2000. Chlorophyll fluorescence - a practical guide. Journal of Experimental Botany 51: 659-668.

Méndez, M. \& Karlsson, P.S. 1999. Costs and benefits of carnivory in plants: Insights from photosynthetic performance of four carnivorous plants in a subarctic environment. Oikos 86: 105-112.

Miguel, S., Hehn, A. \& Bourgaud, F. 2018. Nepenthes: State of the art of an inspiring plant for biotechnologists. Journal of Biotechnology 265: 109-115.

Moran, J.A., Booth, W.E. \& Charles, J.K. 1999. Aspects of pitcher morphology and spectral characteristics of six Bornean Nepenthes pitcher plant species: Implications for prey capture. Annals of Botany 83: 521-528.

Moran, J.A. \& Clarke, C.M. 2010. The carnivorous syndrome in Nepenthes pitcher plants: Current state of knowledge and potential future directions. Plant Signaling and Behavior 5(6): 644-648.

Moran, J.A. \& Moran, A.I. 1998. Foliar reflectance and vector analysis reveal nutrient stress in prey-deprived pitcher plants (Nepenthes refflesiana). International Journal of Plant Sciences 159(6): 996-1001.

Netto, A.T., Campostrini, E., de Oliveira, J.G. \& Bressan-Smith, R.E. 2005. Photosynthetic pigments, nitrogen, chlorophyll $a$ fluorescence and SPAD-502 readings in coffee leaves. Scientia Horticulturae 104: 199-209.

Osunkoya, O.O., Daud, S.D., Di-Gusto, D., Wimmer, F. \& Holige, T.M. 2007. Construction costs and physico-chemical properties of the assimilatory organs of Nepenthes species in Nothern Borneo. Annals of Botany 99: 895-906.

Pavlovič, A. \& Saganová, M. 2015. A novel insight into the cost-benefit model for the evolution of botanical carnivory. Annals of Botany 115: 1075-1092.

Pavlovič, A., Singerová, L., Demko, V. \& Hudák, J. 2009. Feeding enhances photosynthetic efficiency in the carnivorous pitcher plant Nepenthes talangensis. Annals of Botany 104: 307-314.

Pawłowska, B., Telesiński, A., Płatkowski, M., Stręk, M., Śnioszek, M. \& Biczak, R. 2017. Reaction of spring barley and common radish on the introduction of ionic liquids containing asymmetric cations to the soil. Journal of Agricultural and Food Chemistry 65: 4562-4571.

Ramette, A. 2007. Multivariate analyses in microbial ecology. FEMS Microbiology Ecology 62(2): 142-160.

Ravee, R., Mohd Salleh, F.I. \& Goh, H.H. 2018. Discovery of digestive enzymes in carnivorous plants with focus on proteases. PeerJ 6: e4914.

Rischer, H., Hamm, A. \& Bringmann, G. 2002. Nepenthes insignis uses a $\mathrm{C}_{2}$-portion of the carbon skeleton of L-alanine acquired via its carnivorous organs, to build up the allelochemical plumbagin. Phytochemistry 59: 603-609.

Rosli, M.A., Azizan, K.A. \& Goh, H.H. 2018. Antioxidant activity of pitcher extracts from three Nepenthes species. Sains Malaysiana 47(12): 3069-3075. 
Sanusi, S.B., Abu Bakar, M.F., Mohamed, M., Sabran, S.F. \& Mainasara, M.M. 2017. Ethnobotanical, phytochemical, and pharmacological properties of Nepenthes species: A review. Asian Journal of Pharmaceutical and Clinical Research 10(11): 16-19.

Setiawan, H., Hakim, L. \& Batoro, J. 2015. Ethnobotany of Nepenthes spp. in Dayak Seberuang people, West Kalimantan, Indonesia. Journal of Biodiversity and Environmental Sciences 7(6): 275-285.

Thanh, N.V., Thao, N.P., Huong, P.T., Lee, S.H., Jang, H.D., Cuong, N.X., Nam, N.H., Kiem, P.V., Kim, Y.H. \& Minh, C.V. 2015. Naphthoquinone and flavonoid constituents from the carnivorous plant Nepenthes mirabilis and their anti-osteoporotic and antioxidant activities. Phytochemistry Letters 11: 254-259.

Thorén, M.L. \& Karlsson, P.S. 1998. Effects of supplementary feeding on growth and reproduction of three carnivorous plant species in a subarctic environment. Journal of Ecology 86: $501-510$

Thornham, D.G., Smith, J.M., Grafe, T.U. \& Federle, W. 2012. Setting the trap: Cleaning behaviour of Camponotus schmitzi ants increases long-term capture efficiency of their pitcher plant host, Nepenthes bicalcarata. Functional Ecology 26: 11-19.

Tušek, M., Curman, M., Babić, M. \& Tkalec, M. 2016. Photochemical efficiency, content of photosynthetic pigments and phenolic compounds in different pitcher parts of Sarracenia hybrids. Acta Botanica Croatica 75(2): 179-185.

Verma, S. \& Mishra, S.N. 2005. Putrescine alleviation of growth in salt stressed Brassica juncea by inducing antioxidative defense system. Journal of Plant Physiology 162: 669-677.

Wang, L., Zhou, Q., Zheng, Y. \& Xu, S. 2009a. Composite structure and properties of the pitcher surface of the carnivorous plant Nepenthes and its influence on the insect attachment system. Progress in Natural Science: Materials International 19(12): 1657-1664.

Wang, L.S., Wang, L., Wang, L., Wang, G., Li, Z.H. \& Wang J.J. 2009b. Effect of 1-butyl-3-methylimidazolium tetrafluoroborate on the wheat (Triticum aestivum L.) seedlings. Environmental Toxicology 24: 296-303.

Yu, L., Haley, S., Perret, J., Harris, M., Wilson, J. \& Qian, M. 2002. Free radical scavenging properties of wheat extracts. Journal of Agricultural and Food Chemistry 50: 1619-1624.

Yulita, K.S. \& Mansur, M. 2012. The occurrence of hybrid in Nepenthes hookeriana Lindl. from Central Kalimantan can be detected by RAPD and ISSR markers. HAYATI Journal of Biosciences 19: 18-24.

Jacek Wróbel, Urszula Przybylska \& Arkadiusz Telesiński* Department of Bioengineering

West Pomeranian University of Technology in Szczecin Faculty of Environmental Management and Agriculture 17 Słowackiego St

71-434 Szczecin

Poland

Mariola Wróbel

Department of Landscape Architecture

West Pomeranian University of Technology in Szczecin

Faculty of Environmental Management and Agriculture

3A Papieża Pawła VI St

71-459 Szczecin

Poland

*Corresponding author; email: arkadiusz.telesinski@zut.edu.pl

Received: 3 September 2018

Accepted: 16 Jun 2020 